\title{
Effect of Titanium Carbide Content on the Corrosion Behavior of Al-TiC Composites Processed by High Energy Ball Mill
}

\author{
El-Sayed M. Sherif ${ }^{1,2, *}$, Hany S. Abdo ${ }^{1,3}$, Khalil A. Khalil ${ }^{3,4}$, Ahmed M. Nabawy ${ }^{1}$ \\ ${ }^{1}$ Center of Excellence for Research in Engineering Materials (CEREM), Advanced Manufacturing \\ Institute, King Saud University, P. O. Box 800, Al-Riyadh 11421, Saudi Arabia \\ ${ }^{2}$ Electrochemistry and Corrosion Laboratory, Department of Physical Chemistry, National Research \\ Centre (NRC), Dokki, 12622 Cairo, Egypt \\ ${ }^{3}$ Mechanical Design and Materials Department, Faculty of Energy Engineering, Aswan University, \\ Aswan 81521, Egypt \\ ${ }^{4}$ Mechanical Engineering Department, King Saud University, P.O. Box 800, Riyadh 11421, Saudi \\ Arabia \\ *E-mail: esherif@ksu.edu.sa, emsherif@gmail.com
}

doi: $10.20964 / 2016.06 .18$

Received: 6 March 2016 / Accepted: 29 March 2016 / Published: 4 May 2016

In this study, three aluminum-titanium carbide (Al-TiC) composites having the chemical composition of $\mathrm{Al}-15 \% \mathrm{TiC}, \mathrm{Al}-25 \% \mathrm{TiC}$, and $\mathrm{Al}-35 \% \mathrm{TiC}$ were manufactured. The powders of the composites were ball milled in situ using a high energy ball mill and melted in a high frequency induction heat furnace before being consolidated at $130{ }^{\circ} \mathrm{C}$. The effect of increasing the TiC content on the corrosion of the fabricated composites in $3.5 \% \mathrm{NaCl}$ solutions was investigated using open-circuit potential, electrochemical impedance spectroscopy, cyclic polarization, and current-time at constant potential techniques. The surface of the corroded composites was examined using scanning electron microscopy. All results were consistent with each other confirming that the resistance of $\mathrm{Al}$ composites against corrosion remarkably increased with increasing the $\mathrm{TiC}$ content in the composite. This occurred via lowering the corrosion current, corrosion rate, and the potentiostatic current with time at $100 \mathrm{mV}$ vs. $\mathrm{Ag} / \mathrm{AgCl}$, as well as enhancing the polarization resistance with increasing the weight percent of $\mathrm{TiC}$ in the manufactured $\mathrm{Al}$ composite.

Keywords: Al-TiC composites; ball milling; chloride solutions; corrosion; EIS; polarization

\section{$\underline{\text { FULL TEXT }}$}

(C) 2016 The Authors. Published by ESG (www.electrochemsci.org). This article is an open access article distributed under the terms and conditions of the Creative Commons Attribution license (http://creativecommons.org/licenses/by/4.0/). 